\title{
AMBITION LEVEL AND ITS RELATION TO EXCESSIVE COMPETITION AMONG MUSICALLY GIFTED STUDENTS AT THE HIGHER INSTITUTE OF MUSICAL ARTS IN KUWAIT
}

\author{
Mashail K. H. Boshehri ${ }^{1}$, Fatima Ahmed Al-Jasim² ${ }^{2}$ and Mohammed J. Jamalallail ${ }^{3}$ \\ ${ }^{I}$ Researcher in Gifted Education \\ ${ }^{2,3}$ Arabian Gulf University, Bahrain
}

\begin{abstract}
This study aimed at investigating the Ambition Level and its Relation to Excessive Competition among Musically Gifted Students at the Higher Institute of Musical Arts in Kuwait. The researcher used the Descriptive Method. The study sample consisted of (123) students (69 males) and (54 females). The researcher used two instruments to gather information, the scale of ambition level and the scale of excessive competition. The study results showed the following: there are no statistical significance between the mean of musically gifted students in Kuwait on the dimensions of ambition (optimism, acceptance of novelty, tolerance of frustration) by different specialties, except the dimension of the ability to set goals where there were statistical significant differences in favor of students in the piano specialty. The results also showed that there were no statistically significant differences between the means of musically gifted students in Kuwait in the total score on the scale of excessive competition depending by different specialties. There was an average, positive and statistically significant correlation between the total score of the ambition level ambition and the total score of the excessive competition among musically gifted students. The level of competition among musically gifted students can be predicted from the dimensions of ambition level.
\end{abstract}

Keywords: Ambition Level, Excessive Competition, Musically Talented, Kuwait

Study Background

Ambition is one of the most important features that have played a major role in the rapid development around the world in recent times. It is the drive that sharpens mettles and organize ideas to raise the level of life from one level to another advanced one. As long as the human being has ambition, there is no limit to scientific and civilizational development because it is one of the important factors influencing human activities and ideas. The level of nation's progress is measured by the ambitions of their members. Thus, ambition can be considered one of the most important constants that can distinguish one person from another, and this constant is affected by environmental, psychological and social factors.

The level of ambition is the motive and impulse for work to raise attainment, achievement and success in various areas, as the level of ambition is an essential part of the psychological construction of the human being. It promotes optimistic beliefs in the individual to be able to control various forms of psychological pressure. The person who believes in his ability to achieve his intention can manage his life in a more subjective and active manner, which in turn increases his sense of control over the environment and its challenges (Harbi, 2014).

The level of ambition is usually related to gifted students due to the mental characteristics and traits they possess. High ambition is one of the characteristics of the gifted student. The gifted have many characteristics such as the ability to recognize relationships, strong memory, the multiplicity of interests, the perception of substances, the high expectations of self and others, vulnerability, compassion, and the desire to be accepted by others. They are emotionally stable and less prone to nervousness and mental distraction than ordinary students. 
Their thinking is characterized by quality, originality and addressing and treating ideas. They have a wide range of interests, and they are hard workers. They feel joy of achievement, and they have motivation to find new ways to work. They are more challenging and have a hard time backing back. They are characterized by divergent thinking, excitement and deep awareness. Most gifted people are distinguished in cognitive processes, moral maturity, leadership and good humor (Garwan, 2004). ).

Al-Jabbari's study (2008) revealed that the level of psychological and social compatibility and the level of ambition among the students of the Technical Institute in Kirkuk is higher than the assumed mean in the scale. There is a negative correlation between psychological and social compatibility and the level of ambition, and there are no statistically significant differences in psychological and social compatibility and its relation to the ambition of the students of the Institute based on the variables of gender and specialization.

Barakat's study (2009) dealt with the relation of self-concept to the ambition level of Al-Quds Open University students in light of the variables of gender, specialization, and the academic achievement. The results of the study showed that the level of self-concept and the level of ambition of the study sample was within the average level, and that there is a positive correlation between the self-concept and the ambition level of the university's students. The results also showed that there were statistically-significant differences in the grades of students on the scales of self-concept and the ambition level based the variable of academic achievement in favor of the student group with high achievement, and there was were significant differences in these grades based gender and specialization.

The aim of Salem, Qumbel and Al-Khalifa's study (2012) was to find out the correlation between achievement motivation, locus of control, ambition level, and academic achievement of university students in Sudan. The study showed a statistically significant negative correlation between the achievement motivation and locus of control, a positive correlation between the achievement motivation and ambition level, and a statistically significant interaction between the levels of achievement motivation and levels of locus of control over scholastic attainment.

The aim of Kazmi's study (Kazmi, 2012) was to identify anxiety as an indicator of the ambition level among gifted students as well as the relationship between ambition and anxiety among academically superior students. The results of the study showed that the achievement pattern of students depends on the level of ambition and anxiety. The more the students' anxiety to get higher grades, the less their ambition; whereas students with no anxiety have a higher level of ambition.

The aim of Salhi's study (2013) was to reveal the correlation between the psychological stress and the level of academic ambition of students residing in the University of Ouargla. The study sample consisted of female and male and female students residing in the university dorms. The sample size was 255 students. The study used the scale of the psychological stress as well as the scale of ambition level prepared by the researcher. The results of the study showed that there were no differences between the female and male students residing in the university dorms in the level of psychological stress. The results of the study also showed that there were no differences between the students residing in the university dorms in the degree of psychological stress according to their academic grade in the first year and third year. The results of the study also showed there were differences in the psychological stress level among students from the Faculty of Social and Human Sciences and the Faculty of Natural Sciences and Life.

The aim of Chen's study (Chen, 2014) was to identify the impact of self-efficacy on the ambition level of college students and to identify the differences between international and local students in the international community colleges of the in the United States in how self-efficacy affect the ambition level of students. The results of the study showe there were no statistically significant differences in the level of self-efficacy among international and local students. The results of the study showed that the factors of self-efficacy (effort, 
initiation, and time management) affect the ambition level of both international and local students in community colleges.

There is a clear assumption regarding the ambition level and the intensity of goal pursuit that the high level of ambition simulates the behavior of the student and perpetuates and drive this behavior towards a specific goal. The results of Cochran's study (Cochran, 2009) who is one of the first researchers to be concerned with the topic of ambition and the level of excessive competition and conflict among gifted students. Gifted, highly ambitious students are found to be highly motivated and often seek rewards or awards by seeking more learning.

Gallagher's study (2002) shows that low motivation, perseverance and ambition of the gifted are influenced by many factors, the most important of which are environmental factors and conditions surrounding them, which appear in the methods of education, which depend on strict and harsh methods and the lack of freedom of opinion and self-reliance. Parents and teachers don't show encouragement and appreciation for achievement, which lead to a weak parental relationship between children and parents and between the teacher and students. Gallagher shows that the gifted person in this case may resort to the group of comrades and colleagues to obtain gratification, satisfaction and appreciation. Hence, he show behaviors that may be negative towards the family and the school and this leads to increased punitive aspects of the gifted, which in turn affects their level of ambition and perseverance for learning and acquiring skills.

Sanda, Harrod and Hamilton (as reported in Attar, 2012) say that gifted students do not develop skills and social relationships because they do not feel strong competition among peers and thus cancel their friends' presence in the same level of sharing interests, dispositions and needs. As a result, they feel loneliness and isolation. The more the mental age and level of intelligence or talent, the greater the gap or space between gifted students and ordinary colleagues. They become unacceptable and very competitive, and do not feel comfort and harmony with them, leading to more loneliness and withdrawal.

Competition is one of the fundamental aspects of social relationships within peer groups. Each gifted teenager has a special style of competition, which appears in his own requirements and defines the goals he is working hard to achieve. In adolescence, the individual has an awareness of many aspects that surround him, such as the social and economic aspects of his family. If he reaches the middle stage of education, he will be aware of the meanings of social symbols, just like mature adults. In addition, the phenomenon of competition has many entanglements in the attitudes of the gifted towards achieving personal fulfillment. It compels the responsible person whether in the family or school to take full precautions in how to deal with the gifted teenager because of his gravity that reflects positively or negatively on the family and society (Cochran, 2009).

Although competition is a strong and vital motivation in its wide use among students in learning in the classroom, which in turn develops the performance of musically gifted students, it shows talents randomly and with organization, resulting in the loss of the importance of talent. It may turn into excessive competition when it turns into selfishness and individuality in the behavior of students, and jealousy and progress appear more. The student may resort to illegitimate and twisted methods to show his talent as the best among his peers (Cantador\&Conde, 2010).

One of the studies aimed at identifying the level of scientific competitiveness among graduate students and the impact of academic competition on students in the educational system is Kretsinger's study (2003). The results showed that the focus on excellence is the motivation of many students towards competition. The results also showed that students depend on illegal methods to obtain high grades and achieve excellence because of the competition motivated, which affects the psychology of students and their relations with each other.

The aim of Ponzo's study (2009) was to identify the impact of competition among students on their academic achievement. The results of the study showed a statistically significant direct correlation between the academic 
Mashail KH. Boshehril, Fatima Ahmed Al-Jasim and Mohammed J. Jamalallail/Ambition Level and its Relation to Excessive Competition among Musically Gifted Students at the Higher Institute of Musical arts in Kuwait

performance of students and the degree of competition. The students who achieved better results had schools providing more competitive environments.

Among the studies that examined the impact of competition in education, the advantages and disadvantages of competition among students themselves during their learning process, and the impact of competitive learning on student motivation and academic performance is the study of Cantador and Conde (Cantador\&Conde, 2010). The results showed the need to balance competition and cooperation, and to focus on learning objectives rather than competition itself. The results of the study showed that there is an impact of competition on students' academic achievement.

Lam's study (2010) examined the effects of competition on the motivation of Chinese students in the classroom environment. The study used the experimental method as the researcher relied on taking notes during the writing lesson. The results of the study showed that the competitive group was more distinguished in academic performance and tend to learn more. This group relied on self-assessment after failure. The results of the study showed no statistically significant differences between non-competition and achievement.

Joanne and Fong's study (Joanne \& Fong, 2015) showed that competition within the classroom reduced selfefficacy among students, while there was no self-efficacy among students with the lack of competition among students for writing, as there was no significant change in observation.

The results of previous studies support the conclusion that the use of competition in illegal ways may affect the psychology and academic achievement of students, and focus should be on learning objectives rather than competition.

Since the gifted has multiple different talents, musical excellence is considered one of the most important types of talents of students. Al-Momani et al. (2011) notes that arts are one of the most important extracurricular activities in students' cognitive and creative development, as they provide serious opportunities for the development of social, emotional and creative skills such as developing self-esteem, developing personality traits and the ability to recognize individual differences between individuals. It is also a fertile way to express oneself in a non-verbal way and represents a high level of thinking. It paves the way for the practice of different types of arts, which will lead to the development of creative skills and cognitive abilities of students.

In this context, Boyd's study (2013) points out that the arts curriculum offered to gifted students in art institutes is an important part of the teaching process, ensuring that arts are an important criterion for judging the quality of education as they provide those students with many and varied opportunities in various artistic fields such as the educational theater, drawing, singing, chanting and music. Music is a form of art that is consistent with the programs of the academically talented and gifted. It is found within the range of multiple intelligences identified by Gardner in his famous theory, referring to the level of musical intelligence. The individual with musical intelligence distinguishes the multiple different musical tones and recognizes its temporal rhythm with a sense of melodic modes, enhanced ability to process sounds and musical melodies for the purpose of creating tunes and musical compositions, excitement for the emotional effects of music elements, and mastery and professionalism of playing musical instrument(s) (KendEr, 2000).

Given the importance of this topic, the current research considers there is an urgent need to identify the relationship between the level of ambition and excessive competition among musically gifted students at the Higher Institute of Musical Arts in of Kuwait. 


\section{Research Problem}

Ambition is characteristic of gifted students in all fields, and the musically gifte students are no exception. It is an influential factor and a motivation for achievement and excellence. It also affects the level of his tendency towards competition. It may raise the level of his ability to compete and excel others. On the other hand, this competition may turn into an illegal competition and affects the abilities and skills of the gifted in the field of his talent and excellence.

Therefore, the problem of research is to verify the relationship between the level of ambition and the excessive competition of musically gifted students at the Higher Institute of Musical Arts in Kuwait.

The research seeks to answer the following questions:

1. What is the ambition level of musically gifted students at the Higher Institute of Musical Arts in Kuwait?

2. What is the level of excessive competition among musically gifted students at the Higher Institute of Musical Arts in Kuwait?

3. What is the correlation between the ambition level and the excessive competition among musically gifted students at the Higher Institute of Musical Arts in Kuwait?

4. Can the competition level among musically gifted students be predicted through the dimensions of the ambition level of?

\section{Research Importance}

The importance of research is twofold:

\section{Theoretical Importance}

1. The research contributes to the identification of an important factor affecting the ambition level, which is the competition among the gifted and its relation to the factor of excessive competition, which may affect the way the student's ambition forms to become more selfish and introverted in his behavior. This issue may be important to many educators in the field of psychology and requires attention and study from other aspects.

2. Investigate the impact of some factors affecting the musically gifted students to provide the appropriate atmosphere and conditions for their growth and to ensure their continued excellence.

3. Research will be an important factor in revealing the most important dimensions of ambition and its relation to the excessive competition among musically gifted students.

4. The importance of research comes from the scarcity of Arabic studies that dealt with the subject of the ambition level and its relation to the excessive competition among musically gifted students in general and the absence of any Arabic study, within the limits of the researcher's knowledge, which dealt with the research topic.

5. This research is an attempt to overcome the shortage in the Kuwaiti environment, especially among musically gifted students at the Higher Institute of Musical Arts in Kuwait, which may provide a solution to the problem of researchers and those interested in this field.

6. Using the scales of the ambition level and excessive competition and adjusting them to suit the musically gifted students in Kuwait.

\section{Practical importance}

1. Using Muawad and Abdul Azim's scale of ambition level (2005) and modifying it to suit musically gifted students in Kuwait. 
Mashail KH. Boshehril, Fatima Ahmed Al-Jasim and Mohammed J. Jamalallail/Ambition Level and its Relation to Excessive Competition among Musically Gifted Students at the Higher Institute of Musical arts in Kuwait

2. UsingMoawad and Mohammed's scale of excessive competition (1998) and modifying it to suit musically gifted students in Kuwaitand the Kuwaiti environment.

3. Make appropriate recommendations to reduce the intensity of competition and its disadvantages to the ambition level of musically gifted students by providing the necessary care.

\section{Research Terms}

\section{Musical talent:}

It is defines as the ability to recognize, produce, and appreciate different musical styles. This talent appears among students who have a sense of sound level, rhythm, poetic meter, timbre, tune and tones of different degrees and perceiving their meanings (Feierabend, 2015: 1).

\section{Ambition Level:}

It is a relatively consistent feature that distinguishes individuals from each other in readiness and access to goals characterized by a kind of difficulty, struggle, responsibility, perseverance and tendency to excel (Yousfi, 2013, 38).

\section{Excessive Competition:}

Rikman et al. (1996) defines excessive competition as an indeterminate need in the individual to compete and win while avoiding loss at all costs as a means of maintaining or reinforcing feelings of self-entitlement with a tendency to manipulate, aggressively exploit, and discredit others in different situations. (Reported in: Muhammad and Moawad, 1997, 3).

\section{Research Limits}

The following research is confined to the following limits:

- Human Limits: The research was limited to a sample of musically gifted students at the Higher Institute of Musical Arts in Kuwait.

- $\quad$ Time Limits: The research was applied during the second semester 2014/2015.

- $\quad$ Spatial Boundaries: The Higher Institute of Musical Arts in Kuwait.

- Objective Limits: The results of this research were generalized in light of the characteristics of the sample and the tools used in the research.

\section{Research Hypotheses}

First Hypothesis: The level of ambition of musically gifted students varies according to specialties: instruments, voices, composition, piano, education.

Second Hypothesis: The level of excessive competition varies among musically gifted students varies according to specialties: instruments, voices, composition, piano, education.

Third Hypothesis: There is a statistically significant correlation between the ambition level and the excessive competition among musically gifted students. 
Fourth Hypothesis: The level of excessive competition among musically gifted students can be predicted through the dimensions of ambition (optimism - ability to set goals - acceptance of novelty - tolerance of frustration).

\section{Research Methodology}

The current research seeks to determine the relationship between the ambition level and the excessive competition among musically gifted students at the Higher Institute of Musical Arts. Therefore, the study procedures fall under the descriptive approach. It seeks to identify the nature of the relationship between the ambition level of and the excessive competition among musically gifted students at the Higher Institute of Musical Arts.

\section{Research Community}

The target research community here is all male and female students at the Higher Institute of Musical Arts from the first grade to the fourth grade of all specialties (instruments - voices - composition - piano - education) in Kuwait (135) students.

\section{Research Sample}

The sample size was (123) male and female (69 males) and (54 females) with a mean age of 23.3 years. The sample was distributed over the four years. The research sample was divided into the following specialties: 51 students in instruments, 16 students in voices, 13 students in composition, 19 students in piano, and 24 students in education.

\section{Research Tools}

Two tools were used: the scale of ambition level and the scale excessive competition to achieve the research objectives. A survey of 30 students from the preparatory stage at the Higher Institute of Musical Arts was conducted to verify the psychometric properties of the tools.

\section{First: Scale of Ambition Level}

The objective of this scale is to measure the ambition level which consists of four dimensions: optimism, the ability to set goals, acceptance of novelty, and tolerance of frustration. It was prepared by Muawad and AbdulAzim in 2005. They applied the scale on a sample of male and female university students. The scale consists of (36) words and the following dimensions: optimism, the ability to set goals, acceptance of novelty, and tolerance of frustration.

The psychometric characteristics of the scale were calculated by the scale designer by calculating the validity of the scale using the method of criterion validity by calculating the correlation between the scores of the sample on the scale and their scores on the scale of ambition level for adults prepared by Kamlia Abdel Fattah 1975. The correlation coefficient was statically significant (0.86), indicating that the scale has an appropriate degree of validity.

As for the test consistency, the scale designer calculated the stability after applying it to a sample of (152) individuals in two ways. The first was by re-testing after a time interval of two weeks, and the correlation coefficient between the two applications (0.78). The other method was the split-half method as the correlation coefficient between the test halves was calculated and found to be 0.79 . It is not significantly different from the consistency value in the first method. 
Mashail KH. Boshehril, Fatima Ahmed Al-Jasim and Mohammed J. Jamalallail/Ambition Level and its Relation to Excessive Competition among Musically Gifted Students at the Higher Institute of Musical arts in Kuwait

\section{The Method of Grading the Scale}

The scale is graded in incremental way as follows: Always $=4$ - Frequently $=3-$ Sometimes $=2-$ Rarely $=1$. According to the previous grading legend, the maximum score a student can achieve on the total scale is (144) points. The minimum score a student can achieve on the total scale is (36) points. The high score on the scale indicates the high level of ambition, and the low score indicates the low level of ambition. The degree of activating the scale of ambition level for all dimensions of the scale is determined within the tool designed as follows:

The length of the category $=($ the highest value of the scale - the lowest value of the scale $) \div$ the number of categories in the scale

The length of the category $=(4-1) 44=0.75$

In light of this, the values of the arithmetic mean in the case of the scale according to the following categories:

1. If the value of the arithmetic mean falls between ( 1 to less than 1.75), it indicates that the level ambition of the gifted is very low.

2. If the value of the arithmetic mean falls between (2.50 to less than 3.25), it indicates that the ambition level of the gifted is average.

3. If the value of the arithmetic mean falls between (3.25 to less than 4), it indicates that the ambition level of the gifted is high.

\section{The psychometric properties of the scale in the current research:}

\section{1 - Face Validity (judges):}

The scale was presented to a group of judges. They were a number of professors from the University of Bahrain, the Faculty of Basic Education in Kuwait (Appendix B) from the disciplines of psychology and gifted education to judge the validity of the scale items according to the following criteria: the item belonging to the dimension it falls under, its suitability for the age group of the sample, and the wording of the items to suit the sample culture.

\section{2- Construct Validity (Concept)}

To calculate the construct validity, the correlation of the item to the dimension, the degree of the correlation of the item to the total degree, the correlation between the four dimensions of the scale, and the correlation between the dimensions and the total score were calculated.

\section{A. The correlation of the item to the dimension:}

Table 1 shows the correlation degree of the items of each dimension to the degree of the dimension itself.

Table 1 The correlation degree of the items to the dimension on the scale of ambition level.

\begin{tabular}{cccccccc}
\hline \multicolumn{2}{c}{ Optimism } & \multicolumn{2}{c}{ Ability to Set Goals } & \multicolumn{2}{c}{ Acceptance of novelty } & \multicolumn{2}{c}{ Tolerance of frustration } \\
\hline Number & $\begin{array}{c}\text { Correlation } \\
\text { to } \\
\text { Dimension }\end{array}$ & Number & $\begin{array}{c}\text { Correlation } \\
\text { to } \\
\text { Dimension }\end{array}$ & Number & $\begin{array}{c}\text { Correlation } \\
\text { to } \\
\text { Dimension }\end{array}$ & Number & $\begin{array}{c}\text { Correlation } \\
\text { to } \\
\text { Dimension }\end{array}$ \\
\hline 1 & $* * .631$ & 2 & $* * .592$ & 3 & $* * .655$ & 4 & $* .373$ \\
5 & $* * .435$ & 6 & $* * .705$ & 7 & $* * .552$ & 8 & $* * .641$ \\
9 & .338 & 10 & $* * .599$ & 11 & $* * .626$ & 12 & $* * .857$ \\
13 & $* * .764$ & 14 & .343 & 15 & $* * .572$ & 16 & $* * .463$ \\
\hline
\end{tabular}




\begin{tabular}{|c|c|c|c|c|c|c|c|}
\hline 17 & $* * .644$ & 18 & $* * .703$ & 19 & $* * .577$ & 20 & $* * .614$ \\
\hline 21 & $* * .607$ & 22 & $* * .586$ & 23 & $* .431$ & 24 & $* * .659$ \\
\hline 25 & $* * .624$ & 26 & $* * .543$ & 27 & *.439 & 28 & *.403 \\
\hline 29 & $* .450$ & 30 & $* * .661$ & 31 & $* * .520$ & 32 & .355 \\
\hline 33 & .204 & 34 & .340 & & & & \\
\hline 35 & $* * .488$ & 36 & $* * .631$ & & & & \\
\hline
\end{tabular}

Table 1 shows that most of the correlation coefficients of the item scores to the scores of the dimension to which they belong are statistically significant at (0.01) and (0.05), indicating a high degree of consistency of the scale clauses and that they measure where they claim to be measuring, except the correlation coefficient of item (32) in the dimension of tolerance of frustration. It was (0.355), which is not statistically significant. The item will be retained although it is not significant, while modifying the formulation to be clearer for the study sample.

\section{A. Correlation Between Dimensions:}

Table 2 deals with the degree of correlation between the four dimensions of the motivation level (optimism ability to set goals - acceptance of novelty - tolerance of frustration).

Table 2 The correlation degree between the dimensions of the scale of ambition level.

\begin{tabular}{ccccc}
\hline Dimension & $\begin{array}{c}\text { Ability to Set } \\
\text { Goals }\end{array}$ & Acceptance of novelty & Tolerance of frustration & Total Score \\
\hline $\begin{array}{c}\text { Optimism } \\
\text { Ability to Set }\end{array}$ & $* * .571$ & $* * .636$ & $* * .458$ & $* * .822$ \\
$\quad$ Goals & - & $* * .500$ & $* * .830$ & $* * .830$ \\
$\begin{array}{c}\text { Acceptance of } \\
\text { novelty }\end{array}$ & - & - & $* * .538$ & $* * .811$ \\
$\begin{array}{c}\text { Tolerance of } \\
\text { frustration }\end{array}$ & - & - & - & $* * .770$ \\
\hline
\end{tabular}

Table 2 shows that all correlations between dimensions are statistically significant and ranges between $(0.830$ 0.458), indicating a high degree of scale consistency. All correlations between the dimensions and the total score were statistically significant and ranged between (0.830-0.770), indicating a high degree of consistency for the scale sentences.

\section{Scale Consistency:}

The consistency of the four dimensions of the scale was verified using Cronbach's alpha and half-split coefficients. The degree of constancy in the alpha coefficient ranged from $(0.803-0.644)$, and in the half-split, it ranged from $(0.509-0.744)$, indicating high consistency for scale.

\section{Second: The Excessive Competition Scale}

The aim of the excessive competition scale is to measure the degree of excessive competition among students in general and in the current study the students at the Higher Institute of Musical Arts in Kuwait.

It was written and prepared by Muawad and Muhammad in 1998. The applied the scale on a sample of (179) individuals, consisting of (42) items. After extracting the validity and consistency of the scale, some sentences were deleted, so the number of items became (30) items. 
The psychometric characteristics of the scale were calculated by the scale designer by calculating the validity of the scale using more than one method, including: Criterion-Related Validity by calculating the correlation coefficient between the scores of a sample of (118) individuals consisting of (57) males and (61) females on the scale and their grades on the self-assessment scale of Hussein Al-Derini et al. and the narcissism scale of AbdelRaqib El-Beheiry in 1985 . The correlation coefficient was -0.71 and 0.79 respectively.

In 1990 and 1994, Rikman and others calculated the validity of the excessive competition scale by finding the correlation coefficient between it and the scale of both self-assessment and narcissism. The correlation coefficient with the first was negative significant and the second was positive significant. The second way is the construct validity by calculating the internal correlations between the four dimensions of the scale as well as between the total score of excessive competition and each dimension of it. All correlations were found to be significant at (0.01) level. The correlations ranged between 1- and $1+$. The correlations between each factor and the total score of the scale ranged between $(0.83-0.76)$. ). It is significant at the level of $(0.01)$.

As for the test consistency, the scale designer calculated the consistency after applying it to a sample of (118) individuals of (57) males and (61) females in two ways: the value of Cronbach's alpha for both the scale of excessive competition and its four dimensions. The values of alpha ranged between $(0.75-0.66)$. The values of consistency coefficients by the retest method ranged between $(0.81-0.69)$ and it is significant function at $(0.01)$.

\section{The psychometric properties of the scale in the current research:}

\section{Face Validity (judges):}

The scale was presented to a group of judges from the disciplines of psychology and gifted education to judge the validity of the scale items according to the following criteria: the item belonging to the dimension it falls under, its suitability for the age group of the sample, and the wording of the items to suit the sample culture.

\section{Construct Validity:}

\section{A. The correlation of the item to the total score:}

The correlation coefficient of items to the total score was calculated, and Table 3 shows this.

Table 3 Total correlation coefficient of items to the total score

\begin{tabular}{ccccccccccc}
\hline $\begin{array}{c}\text { Sentence } \\
\text { Number }\end{array}$ & $\begin{array}{c}\text { Correlation } \\
\text { to } \\
\text { Dimension }\end{array}$ & $\begin{array}{c}\text { Sentence } \\
\text { Number }\end{array}$ & $\begin{array}{c}\text { Correlation } \\
\text { to } \\
\text { Dimension }\end{array}$ & $\begin{array}{c}\text { Sentence } \\
\text { Number }\end{array}$ & $\begin{array}{c}\text { Correlation } \\
\text { to } \\
\text { Dimension }\end{array}$ & $\begin{array}{c}\text { Sentence } \\
\text { Number }\end{array}$ & $\begin{array}{c}\text { Correlation } \\
\text { to } \\
\text { Dimension }\end{array}$ & $\begin{array}{c}\text { Sentence } \\
\text { Number }\end{array}$ & $\begin{array}{c}\text { Correlation } \\
\text { to } \\
\text { Dimension }\end{array}$ \\
\hline 1 & $* .366$ & 7 & $* .412$ & 13 & $* * .511$ & 19 & $* * .561$ & 25 & $* * .509$ \\
2 & $* * .530$ & 8 & $* .445$ & 14 & $* .405$ & 20 & $* * .610$ & 26 & $* .390$ \\
3 & $* * .726$ & 9 & .235 & 15 & .269 & 21 & $* * .525$ & 27 & $* * .545$ \\
4 & .312 & 10 & $* * .599$ & 16 & $* * .547$ & 22 & .289 & 28 & .343 \\
5 & $* * .695$ & 11 & $* * .478$ & 17 & $* * .567$ & 23 & $* * .459$ & 29 & .280 \\
6 & .317 & 12 & $* .419$ & 18 & $* * .536$ & 24 & $* * .469$ & 30 & $* * .654$ \\
\hline
\end{tabular}

Table 3 shows that most of the correlation coefficients of item scores to the total score of the scale are statistically significant at (0.01), indicating a high degree of consistency for the scale items. However, the correlation of sentences (4-6-9-15-22-28-29) to the total score is not statistically significant but because of the importance of these sentences, they will be retained after modifying its wording.

\section{B. Consistency}


When calculating the consistency degree, it was found that the consistency coefficient Cronbach's alpha was (0.803) and the half-split was (.627).

\section{Research Steps and Procedures}

1. The researcher prepared the research introduction which includes the research preface and its importance, the research problem, objectives, hypotheses, terminology, and methodology, research community, sample, and tools, and methods of statistical processing.

2. The researcher prepared the theoretical framework, which includes the variables of research, the ambition level, excessive competition and musical talent, through the researcher's review of Arabic and foreign references.

3. The researcher prepared the theoretical literature after reviewing the Arabic and foreign studies and researches related to the subject of the research through the published and unpublished $\mathrm{MS}$ and $\mathrm{PhD}$ thesis in the periodicals, scientific sites and university libraries.

4. Standardization of the research tools on the survey sample and calculating its validity and consistency.

5. Choosing a research sample.

6. Application of research tools on the research sample.

7. Conducting the appropriate statistical treatment and verifying the research hypotheses.

8. Reaching and discussing research results in the framework of previous studies and the theoretical framework.

9. Suggesting some recommendations and future proposed research.

\section{Research Results}

\section{Results related to the first hypothesis of the research}

To validate the hypothesis that "the ambition level of musically gifted students varies by specialty," the arithmetic mean and standard deviation of the scores of musically gifted students in Kuwait were calculated on the ambition scale of by specialty, as shown in Table 4.

Table 4 Arithmetic means and standard deviations of the scores of the sample members in the ambition level by different specialties

\begin{tabular}{|c|c|c|c|c|c|c|c|c|c|c|}
\hline \multirow[t]{2}{*}{ Dimension } & \multicolumn{2}{|c|}{ Instruments } & \multicolumn{2}{|c|}{ Voices } & \multicolumn{2}{|c|}{ Composition } & \multicolumn{2}{|c|}{ Piano } & \multicolumn{2}{|c|}{ Education } \\
\hline & $\begin{array}{c}\text { Arith } \\
\text { metic } \\
\text { Mean } \\
\text { s }\end{array}$ & $\begin{array}{c}\text { Standar } \\
\mathrm{d} \\
\text { Deviati } \\
\text { on }\end{array}$ & $\begin{array}{l}\text { Arithm } \\
\text { etic } \\
\text { Means }\end{array}$ & $\begin{array}{c}\text { Standar } \\
\mathrm{d} \\
\text { Deviati } \\
\text { on }\end{array}$ & $\begin{array}{c}\text { Arithme } \\
\text { tic } \\
\text { Means }\end{array}$ & $\begin{array}{c}\text { Standard } \\
\text { Deviatio } \\
\mathrm{n}\end{array}$ & $\begin{array}{c}\text { Arithm } \\
\text { etic } \\
\text { Means }\end{array}$ & $\begin{array}{c}\text { Standar } \\
\mathrm{d} \\
\text { Deviati } \\
\text { on }\end{array}$ & $\begin{array}{c}\text { Arithm } \\
\text { etic } \\
\text { Means }\end{array}$ & $\begin{array}{c}\text { Standar } \\
\mathrm{d} \\
\text { Deviati } \\
\text { on }\end{array}$ \\
\hline Optimism & 3.50 & 0.44 & 3.62 & 0.37 & 3.42 & 0.46 & 3.61 & 0.37 & 3.37 & 0.39 \\
\hline $\begin{array}{l}\text { Ability to } \\
\text { Set Goals }\end{array}$ & 3.37 & 0.49 & 3.36 & 0.35 & 3.42 & 0.39 & 3.62 & 0.43 & 3.12 & 0.49 \\
\hline $\begin{array}{l}\text { Acceptance } \\
\text { of novelty }\end{array}$ & 3.33 & 0.46 & 3.21 & 0.38 & 3.32 & 0.32 & 3.49 & 0.31 & 3.16 & 0.37 \\
\hline $\begin{array}{l}\text { Tolerance of } \\
\text { frustration }\end{array}$ & 3.21 & 0.56 & 3.41 & 0.51 & 3.15 & 0.43 & 3.43 & 0.48 & 3.15 & 0.45 \\
\hline Total Score & 3.35 & 0.42 & 3.40 & 0.33 & 3.33 & 0.34 & 3.54 & 0.35 & 3.20 & 0.34 \\
\hline $\begin{array}{l}\text { Judgment } \\
\text { Level }\end{array}$ & & High & & High & & High & & High & & $\begin{array}{c}\text { Averag } \\
\mathrm{e}\end{array}$ \\
\hline
\end{tabular}


Mashail KH. Boshehril, Fatima Ahmed Al-Jasim and Mohammed J. Jamalallail/Ambition Level and its Relation to Excessive Competition among Musically Gifted Students at the Higher Institute of Musical arts in Kuwait

Through the table, the arithmetic means for piano students was 3.40, followed by the arithmetical mean for voices students (3.40), followed by the arithmetic mean for instruments students (3.35), followed by the arithmetic mean for the composition students of the students of the composition (3.33), and followed by the arithmetic mean for students of the education specialty which was (3.20). We note that there are apparent differences for the sample in the ambition level according to different specialties. Based on these results, it can be judges that the ambition level was high in the specialty of instruments, voices, composition and piano, while the ambition level among the students of education was average. To examine the significance of these differences, one-way analysis of variance (ANOVA) was used. Table 5 shows the results of this test.

Table 5 Results of one-way analysis of variance (ANOVA) to detect the significance of differences in the ambition level according to different specialties

\begin{tabular}{|c|c|c|c|c|c|c|}
\hline Dimension & $\begin{array}{l}\text { Variance } \\
\text { Source }\end{array}$ & $\begin{array}{l}\text { Sum of } \\
\text { Squares }\end{array}$ & $\begin{array}{c}\text { Freedom } \\
\text { Scores }\end{array}$ & Mean Square & $\mathrm{F}$ value & $\begin{array}{c}\text { Significance } \\
\text { Level }\end{array}$ \\
\hline \multirow{3}{*}{ Optimism } & $\begin{array}{c}\text { Between } \\
\text { Groups }\end{array}$ & 0.98 & 4 & 0.25 & 1.41 & \multirow{3}{*}{0.234} \\
\hline & $\begin{array}{l}\text { Within } \\
\text { Groups }\end{array}$ & 20.43 & 118 & 0.17 & & \\
\hline & Total & 21.41 & 122 & & & \\
\hline \multirow{3}{*}{$\begin{array}{l}\text { Ability to set } \\
\text { goals }\end{array}$} & $\begin{array}{c}\text { Between } \\
\text { Groups }\end{array}$ & 2.77 & 4 & 0.69 & 3.35 & \multirow{3}{*}{0.012} \\
\hline & $\begin{array}{l}\text { Within } \\
\text { Groups }\end{array}$ & 24.38 & 118 & 0.21 & & \\
\hline & Total & 27.14 & 122 & & & \\
\hline \multirow{3}{*}{$\begin{array}{l}\text { Acceptance } \\
\text { of novelty }\end{array}$} & $\begin{array}{c}\text { Between } \\
\text { Groups }\end{array}$ & 1.29 & 4 & 0.32 & 2.04 & \multirow{3}{*}{0.093} \\
\hline & $\begin{array}{l}\text { Within } \\
\text { Groups }\end{array}$ & 18.59 & 118 & 0.16 & & \\
\hline & Total & 19.88 & 122 & & & \\
\hline \multirow{3}{*}{$\begin{array}{l}\text { Tolerance of } \\
\text { frustration }\end{array}$} & $\begin{array}{c}\text { Between } \\
\text { Groups }\end{array}$ & 1.56 & 4 & 0.39 & 1.49 & \multirow{3}{*}{0.209} \\
\hline & $\begin{array}{l}\text { Within } \\
\text { Groups }\end{array}$ & 30.74 & 118 & 0.26 & & \\
\hline & Total & 32.30 & 122 & & & \\
\hline \multirow{3}{*}{0.070} & $\begin{array}{c}\text { Between } \\
\text { Groups }\end{array}$ & 1.28 & 4 & 0.32 & 0.070 & \multirow{3}{*}{0.070} \\
\hline & $\begin{array}{l}\text { Within } \\
\text { Groups }\end{array}$ & 16.90 & 118 & 0.14 & & \\
\hline & Total & 18.18 & 122 & & & \\
\hline
\end{tabular}

By reviewing the statistical data of Table 5, which shows the results of the one-way analysis of variance (ANOVA), we note that there are no statistically significant differences between the means of musically gifted students in Kuwait and the total score of the ambition level scale. The results showed that differences between the means of musically gifted students in Kuwait on the dimensions of ambition (optimism, acceptance of novelty, and tolerance of frustration) by different specialties are not statistically significant. The results showed that differences between the means of musically gifted students in Kuwait on the dimension of the ability to set goals were statistically significant. Its significance level was 0.012 , which is less than $(\alpha=0.05)$. To know the position of differences between any two specialties, the Bonferroni test was used for post-comparisons, as shown in Table (6). 
The results of the Bonferroni test shown in Table 6 show that the difference is statistically significant among students in the specialties of education and piano, in favor of students in the piano specialty. Their average score on the dimension of the ability to set goals was the highest.

Table 6 Benfroni test results for post-comparisons to locate the position of significance of differences between means of musically gifted students in Kuwait on the dimension of the ability to set goals

\begin{tabular}{cccccc}
\hline \multicolumn{7}{c}{ The difference between the two means } \\
\hline Specialty & Instruments & Voices & Composition & Piano & Education \\
\hline Instruments & - & 0.01 & 0.05 & 0.25 & 0.25 \\
Voices & - & - & 0.06 & 0.26 & 0.24 \\
Composition & - & - & - & 0.20 & 0.30 \\
Piano & - & - & - & - & $* 0.50$ \\
Education & - & - & - & - & - \\
\hline
\end{tabular}

* Statistically significant at significance level of 0.05

\section{Results related to the second research hypothesis}

To validate the hypothesis that "the level of excessive competition among musically gifted students varies by specialty," the mathematical mean and standard deviation of the scores of musically gifted students in Kuwait were calculated on the scale of excessive competition by specialty, as shown in Table 7.

Table 7 The arithmetic means and standard deviations of the scores of the sample members in the level of excessive competition by specialty

\begin{tabular}{cccc}
\hline \multicolumn{2}{c}{ SpecialtyArithmetic Mean } & Standard Deviation & Judgment \\
\hline Instruments & 3.31 & 0.65 & Average \\
Voices & 3.05 & 0.61 & Average \\
Compositions & 3.16 & 0.55 & Average \\
Piano & 3.34 & 0.68 & Average \\
Education & 3.01 & 0.57 & Average \\
\hline
\end{tabular}

Through Table 7 , the mean of piano students was 3.34 with a standard deviation of 0.68 , followed by the mean of the instruments students which was 3.31 with a standard deviation of 0.65 , followed by the mean of composition students which was 3.16 with a standard deviation of 0.55 , followed by the mean of voices students which was 3.05 with a standard deviation of 0.61 , and followed by the mean of education specialty students which was 3.01 with a standard deviation of 0.57 . We note that there are apparent differences for the sample in the competition level according to different specialties. It's noted that the judgment for all specialties is average and to detect the significance of differences between averages, one-way analysis of variance (ANOVA) was used. Table 8 shows the results of this test.

Table 8 Results of one-way analysis of variance (ANOVA) to detect the significance of differences in the excessive ambition level by different specialties

\begin{tabular}{cccccc}
\hline Variance source & $\begin{array}{c}\text { Sum of } \\
\text { Squares }\end{array}$ & $\begin{array}{c}\text { Freedom } \\
\text { Scores }\end{array}$ & $\begin{array}{c}\text { Mean } \\
\text { Square }\end{array}$ & $\begin{array}{c}F \\
\text { value }\end{array}$ & $\begin{array}{c}\text { Significance Level } \\
\text { Observed }\end{array}$ \\
\hline $\begin{array}{c}\text { Between } \\
\text { Groups }\end{array}$ & 2.20 & 4 & 0.55 & 1.41 & 0.236 \\
Within Groups & 46.16 & 118 & 0.39 & & \\
Totals & 48.36 & 122 & & & \\
\hline
\end{tabular}


Mashail KH. Boshehri1, Fatima Ahmed Al-Jasim and Mohammed J. Jamalallail/Ambition Level and its Relation to Excessive Competition among Musically Gifted Students at the Higher Institute of Musical arts in Kuwait

By reviewing the statistical data of Table 8, which shows the results of the one-way analysis of variance (ANOVA), we note that there are no statistically significant differences between the means of musically gifted students in Kuwait on the total score of the excessive ambition scale. The observed significance level was (0.236) which is more than the previously-determined significance level of (0.05).

\section{Results related to the third research hypothesis}

To validate the hypothesis that "there is a statistically significant correlation between the ambition level and the excessive competition of musically gifted students." The Pearson correlation coefficient (R) between the ambition level and excessive competition among musically gifted students in Kuwait was calculated, and coefficient of determination (R2) was calculated, and it is the square of correlation value, as shown in Table 9.

Table 9 Pearson correlation coefficient and coefficient of determination between the dimensions of the ambition level and excessive competition of musically gifted students musically

Competition (R) Ambition Level Coefficient of Determination (R2)

\begin{tabular}{lcc}
\hline Optimism & $* * .430$ & 0.1849 \\
Ability to to set goals & $* * .400$ & 0.16 \\
Acceptance of novelty & $* * .371$ & 0.1376 \\
Tolerance of frustration & $* * .458$ & 0.2098 \\
Total score & $* * * 488$ & 0.2381 \\
\hline
\end{tabular}

** Statistically significant at significance level of 0.01

Through Table 9, using Pearson correlation coefficient showed that there was a strong, positive and statistically significant correlation between the total score of the ambition level and the total score of competition among musically gifted students in Kuwait. The correlation coefficient was (0.488) at a significance level of less than (0.01). The variance in the ambition level interprets $23.81 \%$ of the variance in the degree of competition, depending on the value of coefficient of determination $\left(r^{2}=0.2381\right)$. The results showed that there was a strong, positive and statistically significant correlation between optimism and the total score of competition among musically gifted students in Kuwait. The correlation coefficient was 0.430 at a significance level of less than 0.01 . The variance in the ambition level interprets $18.49 \%$ of the variance in the degree of competition, depending on the value of coefficient of determination $(\mathrm{r} 2=0.1849)$.

The results also showed that there was an average, positive and statistically significant correlation between the dimension of the ability to set goals and the total score of excessive competition among musically gifted students in Kuwait. The correlation coefficient was 0.400 at a significance level of less than 0.01 . The variance in the level of the ability to set goals interprets $16 \%$ of the variance in the degree of competition, depending on the value of coefficient of determination $(\mathrm{r} 2=0.16)$.

The results also showed that there was an average, positive and statistically significant correlation between the dimension of accepting novelty and the total score of excessive competition among musically gifted students in Kuwait. The correlation coefficient was 0.371 at a significance level of less than 0.01 . The variance in the level of accepting novelty interprets $13.76 \%$ of the variance in the degree of excessive competition, depending on the value of coefficient of determination $(\mathrm{r} 2=0.1376)$. 
The results also showed that there was an average, positive and statistically significant correlation between the dimension of tolerating frustration and the total score of excessive competition among musically gifted students in Kuwait. The correlation coefficient was 0.458 at a significance level of less than 0.01 . The variance in the level of tolerating frustration interprets $20.9 \%$ of the variance in the degree of excessive competition, depending on the value of coefficient of determination $(\mathrm{r} 2=0.2098)$.

\section{Results related to the fourth research hypothesis}

To validate the hypothesis that "the level of excessive competition among musically gifted students can be predicted through the dimensions of the ambition level," the multiple stepwise regression analysis was used as the dimensions of the ambition level are the independent variables and the level of excessive competition for gifted students is the dependent variable.

Table 10 Results of the multiple stepwise regression analysis for the prediction of the excessive ambition level among musically gifted students through the dimensions of ambition level

\begin{tabular}{cccccccc}
\hline $\begin{array}{c}\text { Variance } \\
\text { source }\end{array}$ & $\begin{array}{c}\text { Sum of } \\
\text { Squares }\end{array}$ & $\begin{array}{c}\text { Freedom } \\
\text { Scores }\end{array}$ & $\begin{array}{c}\text { Mean } \\
\text { Square }\end{array}$ & $\begin{array}{c}\text { Correlation } \\
\text { Coefficient } \\
\text { R }\end{array}$ & $\begin{array}{c}\text { Coefficient of } \\
\text { Determination } \\
\text { R2 }\end{array}$ & $\begin{array}{c}\text { Test } \\
\text { Value } \\
\text { F }\end{array}$ & $\begin{array}{c}\text { Significance } \\
\text { Observed }\end{array}$ \\
\hline Regression & 11.79 & 4 & 0.55 & 0.494 & 0.244 & 9.51 & 0.000 \\
Residual & 36.57 & 118 & 0.39 & & & \\
Total & 48.36 & 122 & & & & & \\
\hline
\end{tabular}

The results of Table 10 show that the regression model is generally effective. The level of competition among musically gifted students can be predicted through the dimensions of the ambition level. It was found that the regression model is statistically significant at the significance level of (0.01). Table 11 shows the regression coefficients of the results of multiple stepwise regression analysis for the prediction of the excessive ambition level among musically gifted students through the dimensions of ambition.

Table 11 Regression coefficients for the results of multiple stepwise regression analysis for the prediction of the excessive ambition level among musically gifted students through the dimensions of ambition

Model Level Regression Coefficient

\begin{tabular}{lc}
\hline Regression & 0.655 \\
Optimism & 0.113 \\
Ability to to set goals & 0.175 \\
Acceptance of novelty & 0.150 \\
Tolerance of frustration & 0.330 \\
\hline
\end{tabular}

From Table 11, the prediction equation can be formed as follows:

Competition degree $=0.655+0.113 *($ Optimism $)+0.175 *($ Ability to set goals $)+0.150 *($ accept novelty $)+$ $0.330 *$ (tolerance of frustration)

\section{Discussion of Research Findings}

\section{Discussion of the Findings of the Research First Hypothesis}


The findings showed that there were no statistically significant differences between the means of musically gifted students in Kuwait in the total score on the ambition level by specialty. Their ambition level was also high in all dimensions of ambition. This result is consistent with the study of Yung (1998) which states that the ambition level is influenced by a number of factors, which can be summarized in three areas. The first area is related to the person, his composition, mental abilities, emotional state and future vision. The second is related to factors of the environment around the individual. This may be due to the satisfaction with the specialties studied by students and the conviction that they are useful and appropriate to their tendencies. This may also be attributed to the fact that the Higher Institute of Musical Arts is interested in musical talents unlike other faculties of educational or scientific specialties in Kuwait. As a result, the graduate of the secondary school who is less interested in the scientific subjects and more talented in the musical subjects resorts to the Higher Institute of Musical Arts to hone his artistic talent. The students at the Higher Institute of Musical Arts have high mental capacities through joining this type of specialty as no student can join this specialty without having high artistic mental capacities. These capacities and capabilities distinguish this students from other students in other specialties as his sets his sights on a goal that commensurate with the artistic capacities he has. Then, he develops his plan to reach that goal. This process needs non-trivial mental abilities through which he can judge things, his capacities and what the goal needs. So, the capacities the student has, the higher his ambition level. The researcher thinks that the absence of statistically significant differences in the ambition level of in the sample of the current study despite the different musical specialties can also be attributed to the fact that curricula in these areas receive great attention any care by those who teach students, in addition to the fact that school curricula they teach stimulate their capacities, contributing ultimately to achieving their ambition level.

The findings also showed that the differences between the means of musically gifted students in Kuwait on the dimensions of ambition (optimism, accepting novelty, tolerating frustration) by different specialities are is statistically significant, while the results indicated that the differences between the means of musically gifted students in Kuwait in the dimension of the ability to set goals is statistically significant for students in the piano specialty as their average score on the dimension of the ability to set goals was higher. If there is a high level of ambition on the dimension of the ability to set goals for piano students only, this may be due to the existence of some factors that inspire and enhance the student's ambition. In this case, the student's ambition increases and it is referred to as the situation which affects him. One of these factors may be the presence of a group of people and raters when the student plays solo piano directly. During this, he feels encouragement from others and receives support for his excellence in this aspect, which leads to more ambition to reach a higher level. Piano students also have self-efficacy factors in terms of effort, initiation and time management. They take more shares of musical notes than the rest of the students in other specialities. This increases their ambition level in comparison with other specialties.

\section{Discussion of the Findings of the Research Second Hypothesis}

The findings of the research indicate that there are no statistically significant differences between the means of musically gifted students in Kuwait in the total score on the excessive competition scaly by specialty. This is a satisfactory result because the presence of excessive competition may cause negative behavior among students. This result is consistent with the study of Malini (2011), which states that the use of excessive competition before mastering the scientific material, skill or behavior leads to a negative behavior in students. Excessive competition also lead to the development of vanity and pride in some students and to envy and feelings of weakness in others. This may be due to the fact that the work of art and music in particular is an integrated work on the level of performance. It consists of somewhat different artistic (musical) specialties, and since they participate at the same time in performing the artwork, excessive competition may have no place. Natural or normal (average) occurs among those enrolled in these different artistic specialties on the basis that they are independent to a certain extent and in favor of work and each have a relatively different area. Any amount of excessive competition that may occur among students in different specialties generates negative feelings 
towards others and the desire to place obstacles and constraints to others that prevent them from creativity, excellence and success. This is not required or not possible in musical bands. The excessive competition of one person may lead to a flaw in the entire musical band as reported on the disadvantages of competition (Jimerson, 2003).

\section{Discussion of the Findings of the Research Third Hypothesis}

The findings of the research showed that there is a strong, positive and statistically significant correlation between the total score on the ambition level and the overall score of excessive competition among musically gifted students in Kuwait. This finding may indicate that the ambition level is associated with moderate competition rather than excessive one. That's why the correlations are average. This is because ambition does not put one in jeopardy, i.e. excessive completion. The student seeks to achieve his goal through honest competition. This may be due to the fact that the person who exercises excessive competition is more likely to think about others and reducing their capacities and does not recognize the abilities or qualifications of others. At the same time, he claims that all they have achieved is the result of lying, deceit, cheating, or any other misconduct. He does not focus on personal fulfillment and developing his abilities in his specialty. His ambition is only to prove that others are unable to achieve, belittle them, question their abilities, ethics and honesty, and undermine their credibility in one way or another. He underestimates other students and question their achievements without exerting the effort required to catch up with them and accomplish similar or better achievements.

\section{Discussion of the Findings of the Research Fourth Hypothesis}

The findings of the research show that the competition level among musically gifted students can be predicted from the dimensions of ambition (optimism, the ability to set goals, acceptance of novelty, and tolerance of frustration). Al-Nabhan points out that in order for the prediction to be accurate and meaningful, the correlation coefficient must be strong. The correlation and regression are complementary. Since there is a statistically significant correlation between excessive competition and variables and the regression model is generally effective, we can predict the competition level among students from the dimensions of ambition. This may be due to the fact that the student who has the behavior of excessive competition always focuses on the other student who competes with him and forgets to develop himself and work on developing his skills. His first priority is what the other student achieves and forgets optimism. He always tends to be pessimistic and afraid of getting grades and level less than the level of his colleague. It can be said that the greater the competition the greater the level of ambition to get a high level. The student with excessive competition ignores the drawing plans and setting goals for completion during the specialization. He focuses only on the idea of getting a level higher than his colleagues. He does not care about getting a different skill or capacity outside the scope of his studies. Hence, he does not accept any renewal in his life in contrast to the person who has a positive competition and does not mind to acquire any skill within his objectives to achieve them. This may be because the student who has the behavior of excessive competition often feels failure and frustration when he fails in a certain academic aspect or musical skill. He considers his failure as destructing for his personality and declining in the idea of excessive competition. This generates hatred of other colleagues.

\section{Research Recommendations}

In light of the findings of this research, which proved the importance of the musically gifted, the importance of the ambition level and its relationship to excessive competition. With reference to previous studies, we can propose the following recommendations:

1. Taking care of musically gifted students and guiding them towards raising the level of their ambition and motivation in various fields. 
Mashail KH. Boshehri1, Fatima Ahmed Al-Jasim and Mohammed J. Jamalallail/Ambition Level and its Relation to Excessive Competition among Musically Gifted Students at the Higher Institute of Musical arts in Kuwait

2. Training teachers on how to raise the level of ambition among students, especially the musically gifted in Kuwait.

3. Educating gifted people of all kinds about the importance of competition, distinguishing between illegal excessive competition and stimulating average (moderate) competition that may help to achieve a good learning environment and raise their level of motivation.

4. Focusing on the dimensions of competition and the level of ambition as a strong incentive in the field of learning, which help creativity and innovation, and contribute to improving the performance of academic students

\section{References}

\section{First: Arabic References}

Al-Nabhan, Musa (2006). Fundamentals of Statistics in Education, Humanities and Social Sciences. Second Edition. Al Falah Library for Publishing and Distribution. Al Ain: United Arab Emirates.

Barakat, Ziad. (2009). The Relationship of the Self Concept to the Level of Ambition among the Students of AlQuds Open University and their Relation to some Variables (unpublished master's thesis). Al-Quds Open University, Palestine.

Ben Gathefa, Sharifa. (2014). Decision-making and its Relation to Thinking Methods and Ambition Level of employees in Public Institutions (unpublished doctoral thesis). University of Setif 2, Algeria.

Jabari, Mohammed. (2008). Psychological and Social Compatibility and its Relation to the Ambition Level among Students of the Technical Institute in Kirkuk, Journal of the University of Kirkuk (Humanities), Volume (3), extracted from the link http://www.iasj.net/iasj?func=fulltext\&aId=435 81

Grewan, Fathi. (2004). Talent, Excellence and Creativity. Amman: Arab Thought House.

Harbi, congratulations. (2014). Concern about the Future and its Relation to Self-esteem and the Ambition Level among High School Students in Riyadh City. (Unpublished master thesis) Naif Arab University for Security Sciences, Saudi Arabia.

Salem, Hebatullah, Qumabil, Kubshur, \& Al Khalifa, Omar. (2012). The Relationship between Achievement Motivation, the Control Position, the Ambition Level, Academic Achievement of Students in Institutions of Higher Education in Sudan. The Arab Journal for the Development of Excellence, 3 (4), 81-96.

Salhi, Hana. (2013). The Relationship of Psychological Stress to the Ambition Level of University Students Residing in the University of Ouargla (a memorandum submitted to complete the requirements of the master's degree). University of Ouargla, Algeria.

Attar, Saida. (2012). Problems of Outstanding Students in the Algerian School: A Field Study in Secondary Schools of Tlemcen. Journal of Humanities and Education (8). 200-169

Al-Momani, Mamoun; Hamouri, Khalid; Yunus, Najati\& Al Qaraan, Jehad (2011). The Relationship between the Level of Musical Abilities and Academic Achievement of Academically Outstanding Students. Jordanian Journal of Arts, Volume (4), Issue (1), 29-43.

Yousfi, Dalal. (2013). Social Anxiety and its Relation to the Ambition Level among Students in the Second Year of Secondary School (unpublished master's thesis). University of Mohamed KhiedrBiskra, Algeria.

\section{Second: Foreign References}

Boyd, J. (2013). The relationship between music participation and mathematicsachievement in middle school students. (A Dissertation Presented in Partial Fulfillment of the Requirements for the Degree Doctor of Education) Liberty University, USA.

Cantador, I. \&Conde J. (2010).Effects of competition in education: A casestudy in an e-learning environment. Universidad Autónoma de Madrid Campus de Cantoblanco. Spain.

Chen, Yu. (2014). The influence of self-efficacy on degree aspiration among domestic and international community college students Graduate, Theses and Dissertations. Paper 14026. 
Cochran, C. (2009). Effects of social support on the social self-concepts of gifted Adolescents. Research Gate. University of Virginia, USA.

Cretsinger, M. (2003). Academic competitiveness amonggraduate students. The Graduate School University of Wisconsin-Stout.

Feierabend, M. (2015). Musicand Intelligence in the Early Years, Ph.D.unpublished thesis.

Gallagher, J. (2002). Society's role in educating gifted students: the role of public policy. USA, The National Research Center On The Gifted And Talented.

Jimerson, L. (2003). The competitive disadvantage: Teacher Compensation in Rural America.The Rural School and Community Trust .

Joanne, C. \&fong, L. (2015). Using Medical Incidents to Teach: Effects of Vicarious Experience on Nursing Students' Self-Efficacy in Performing Urinary Catheterization. Journal of Nursing Education, 54 (2)80.

Kazmi, S. (2012).Anxiety as predictor of aspiration amongacademic achievers.The Online Journal of New Horizons in Education. Volume 3, Issue 4.

Kender, M. (2000). an exploration of musical intelligence, (Thesis submitted to the Faculty of Virginia Polytechnic Institute and State University in Partial Fulfillment of the Requirements for the Degree of Masters of Science in Human Development).

Lam, S., Yim P., Law, J. \& Cheung, R. (2010). The effects of competition on achievement motivation in Chinese classrooms.British Journal of Educational Psychology. Volume 74, Issue 2, 281-296.

Malini, K. (2011). The Effects of Unhealthy Competition.Innerspace Therapy

Ponzo, M. (2009). The effects of school competition on the achievement of Italian students. Working Paper $n$. 20.

Young, D. (1998). Ambition, self-concept, and achievement: A structural equation model for comparing rural and urban Students.Journal of Research in Rural Education. Vol. 14, No.1, pp. 34-44 